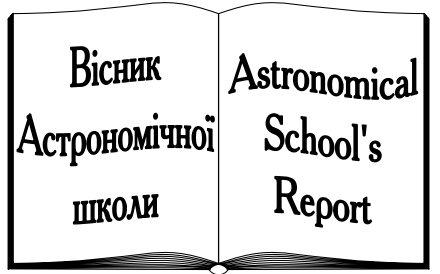

ISSN 2411-6602 (Online)

ISSN 1607-2855 (Print)

Volume $16 \bullet$ Issue $2 \bullet 2020 \quad$ P. $33-37$

https://doi.org/10.18372/2411-6602.16.05

UDC 528.946

\title{
Web-mapping of environmental pollution of the surface waters of the Lviv region
}

\begin{abstract}
A.R.Sohor*, M.M. Fys, A.M. Brydun, M.A. Sohor
Lviv Polytechnic National University, 79013, Lviv, Karpinskyi street 6

The ecological status of the surface waters of the Lviv region is influenced by closely related various factors, namely: soil pollution, atmosphere, change of landscape structure and technogenic congestion of the territory, inefficient work of sewage and treatment facilities, failure of the mapping of coastal water protection and marsh, as well as their non-observance, especially in settlements, pollution and clogging of rivers with household and other wastes, trellising of forests along streams in mountainous terrain. Another important problem that leads to surface water pollution in the region is the lack of water protection zones and coastal protection strips of water bodies in the territory of the region. Absence of planning and mapping materials and uncertainty on the terrain boundaries of water protection zones and coastal protection strips lead to violations of land and water legislation when using them. At present, the state of water bodies in Ukraine, and in particular in the Lviv region is at an unsatisfactory level. The main problems in this area are the progressive nature of the negative impact on the environmental and human health. As at present there is no cartographic material that can visualize the problem of surface water pollution in Lviv region, the main purpose of this work was to create an interactive map of surface water pollution. To achieve this goal, we collected and systematized geospatial statistical mapping materials on the ecological status of the surface waters of the Lviv region. The necessary software for the development of the interactive map is identified and its possibilities are examined. An algorithm for loading geospatial data into the created web resource has been developed. The application template for the creation of web-maps of the monitoring network of the surface water of the Lviv region and the discharge of sewage for 2017-2018 in ArcGIS Online environment was selected. Thus, two interactive maps of ecological pollution of Lviv region's surface water in ArcGIS Online were developed.
\end{abstract}

Keywords: geospatial data; State Service of Geodesy Cartography and Cadastre; ecological mapping; surface water pollution; interactive map; ArcGIS Online environment; Microsoft Office Excel environment.

\section{INTRODUCTION}

An analysis of modern scientific publications has shown that the problem of surface water pollution requires considerable attention and detailed study, since the negative change in nature affects the environment and the conditions of existence of all mankind. It is ecological mapping that can clearly reflect the ecological quality of surface water and draw some conclusions [1, 4, 10-12].

Ecological mapping differs from a number of other thematic (geological, geomorphological, soil) mapping fields with the complexity of determining its subject area. The main object of ecological mapping are ecosystems of different rank, the extent of anthropogenic impact on the environment, nature conservation measures, the relationship of organisms and environment, environmental situations $[2,8,13-15]$.

Ensuring balanced, ecologically safe development of individual territories of the state is possible only under the understanding of the functioning of natural and anthropogenic complexes within them. Such a holistic approach to the study of natural and man-made objects and the use of environmental information obtained on its basis in the decision-making process determine the importance and necessity of applying modern geographical methodologies $[3,7]$.

At present, the state of water bodies in Lviv region is at an unsatisfactory level. The main problems in this area are the progressive nature of the negative impact on the environmental health and human health [3].

Unfortunately, at the moment there is no cartographic material that can visualize the problem of ecological pollution of the surface waters of Lviv region. Therefore, the main purpose of this work is to create an interactive web-map of surface water pollution in Lviv region [6].

\section{DATA AND METHODS}

In this work, an interactive web-map was created using the ArcGIS Online software environment (https:// www.arcgis.com/).

ArcGIS Online is a platform that is the world leader in geo-information systems (GIS) platforms and is used worldwide for the application of geographical knowledge in the areas of public administration, business, science, education and media. ArcGIS allows you to publish geographic information for access and use by

*Sohor Andrii Romanovych; $\varangle$ and.sohor@gmail.com 
any user. Therefore, it is an environment for creating and sharing maps, displaying applications and data, which allows you to use, create and configure access to maps, scenes, layers, applications and data [5].

ArcGIS Online makes it easy to upload files and add content from an electronic cloud. Many file types are supported, including spreadsheets, KML, GeoJSON, and regular geospatial files. If you need to refine your data, ArcGIS Online includes tools to help you prepare for visualization and analysis. Interactive web-maps support the visualization, editing and analysis of information, and can be viewed using mobile and computer devices [9].

One of the types of maps that can be used in ArcMap is a web-map that can be created in a web-browser using the ArcGIS.com map viewer and used by any ArcGIS client - ArcGIS for Desktop, ArcGIS mobile and web-applications and etc. Access to all ArcGIS mapping services is provided by creating web-maps. It is also possible to use ArcGIS for Desktop to publish the map as a service [6].

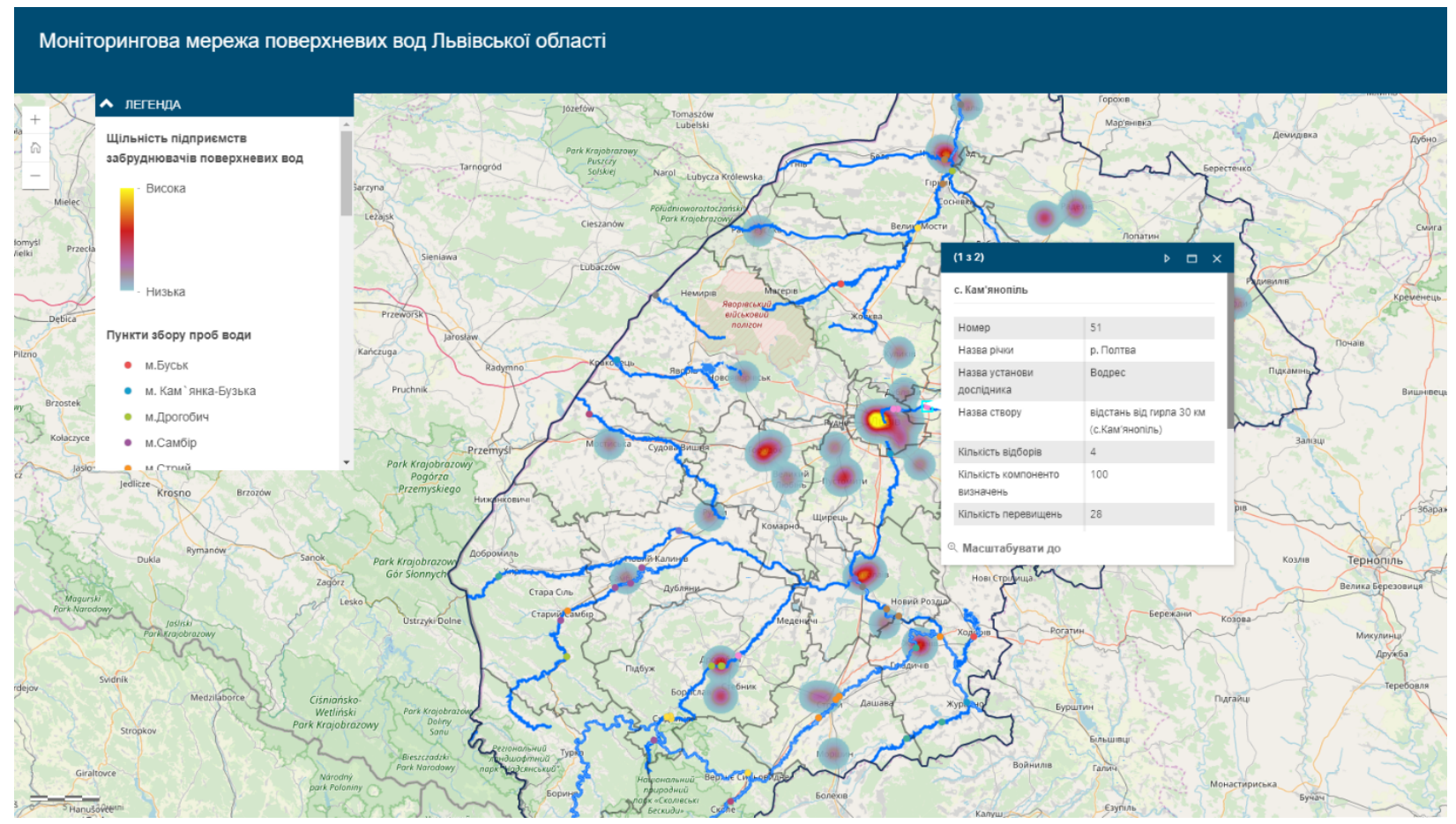

Fig. 1. Map of the surface water monitoring network of Lviv region (C) OpenStreetMap contributors, https://www.openstreetmap.org/copyright)

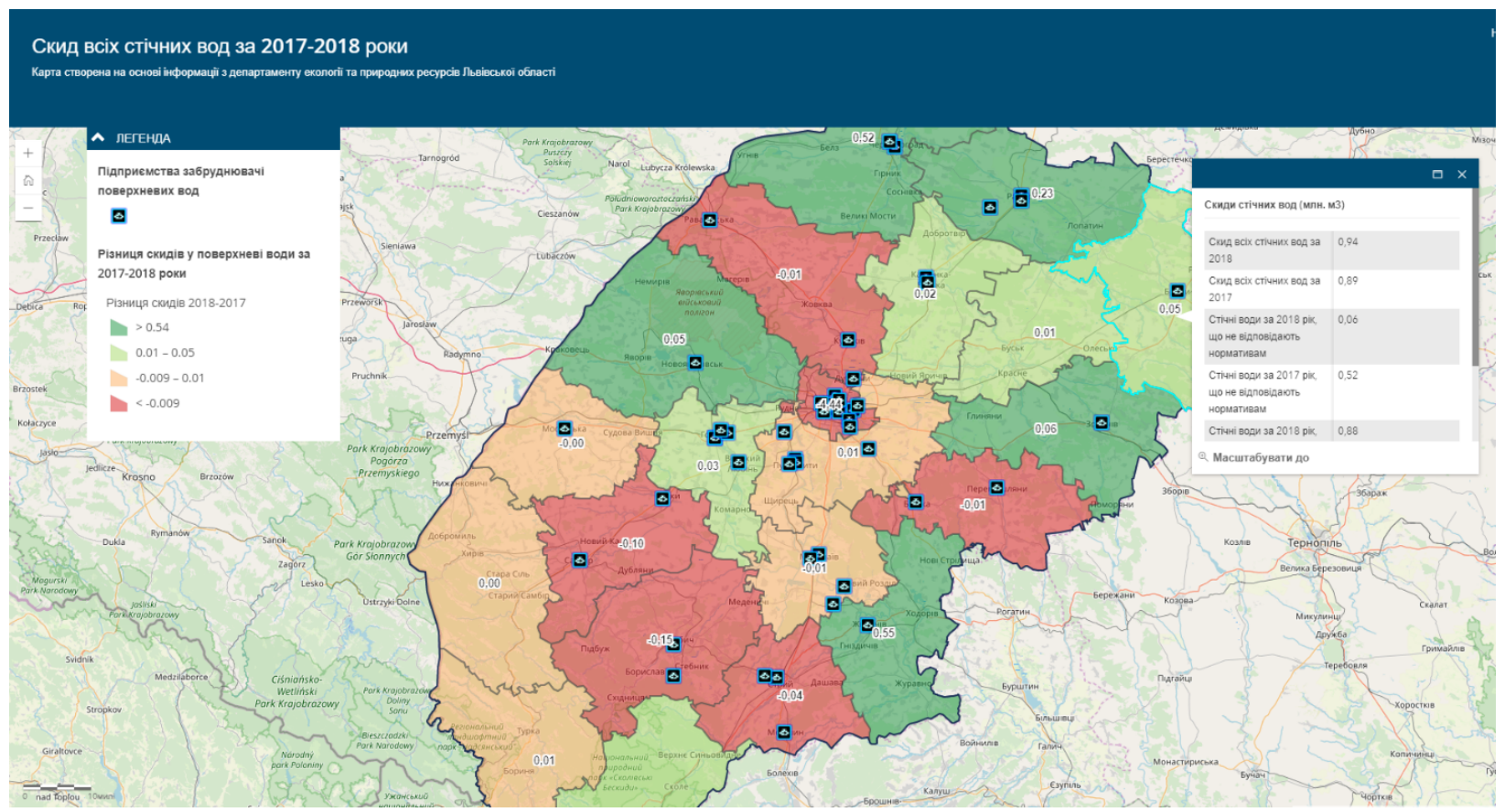

Fig. 2. Wastewater discharge map for 2017-2018

(C) OpenStreetMap contributors, https://www.openstreetmap.org/copyright) 
In order to use the web-application and build the web-maps in it, you need to create an account that will be publicly available for viewing and using online. This record is free of charge and allows you to use a personal online storage facility and to create, process and save files and maps.

ArcGIS enables you to synthesize data from multiple sources into one linked geographic view. These data sources include information from geographic databases, tabular data from database management systems and other systems, files, spreadsheets, photos and videos with geographical labels, KML, CAD-data, real-time sensor data, aerospace and satellite imagery, etc. Virtually any entry with a geographical reference, such as street, city, land ID, GPS-coordinates, etc., can be accessed on the map and can be accessed [5, 6, 9].

Against this background, to create an interactive web-map we used the quite convenient and popular ArcGIS Online environment. In order to get started in your chosen environment, you need to collect and structure data in Microsoft Office Excel. In our case, three Excel-spreadsheets were developed, namely:

- with information on recorded excesses by indicators at enterprises surveyed by the State Inspectorate for Inspection in the Lviv region during 2014-2018;

- with information on wastewater discharges after treatment facilities;

- with information on observations of surface water quality on the border rivers.

For visualization, we will use the map OpenStreetMap in the ArcGIS Online software environment with the borders of Lviv region and outside the regions.

Many we-maps contain interactive features, such as a base map gallery, which allows you to switch between maps, such as between snapshots and street networks, as well as measurement tools, pop-ups that display attributes of selected objects, and buttons to display data from over time. Maps are created using layers of data from services and files to convey a specific message or provide the necessary capabilities for the map. Developed maps can be opened in regular web-browsers and mobile devices. These maps can be shared through links and inserts on websites.

In order not to overload the map, it was decided to develop two different interactive maps, each of which would display specific information.

To begin with, let's determine the location of surface water pollutant businesses and water sampling points.

To solve this problem, we used the Google Maps environment, indicating the location of each business, as well as the location of sampling points on the rivers.

Further, this information should be downloaded into ArcGIS Desktop, for this purpose we export the item layer to $\mathrm{KML} / \mathrm{KMZ}$.

After these actions, we open ArcGIS Desktop, to which a layer with areas of Lviv region has been previously added, open ArcToolbox/Conversion Tools/From KML/KML to Layer. We get the downloaded KML-file in ArcGIS.

Using the ArcToolbox function, we export this downloaded KML-file to Shapefile. Then we use an additional environment with "Value $M$ " and "Value Z" to store route and altitude information.

After loading the data into ArcGIS Desktop, you must select all rivers from which water samples were taken. To do this, we use the function Select By Attributes, where they have to choose the right river.

As a result of all the above actions, the following map was obtained in the ArcGis software environment.

After the map is loaded in the ArcGIS Desktop software, all this data must be downloaded into ArcGIS Online, for this purpose all the materials processed in Shapefile will be exported to the selected folder and archived.

After styling, symbolizing and processing all layers, the map can be moved to the public using the Share function. This feature allows you to either insert an existing site or develop your own application. In this case, we have developed our own application.

\section{RESULTS AND DISCUSSION}

As a result of these actions, we created two maps with different themes, namely:

- Surface water monitoring network in Lviv region (Fig. 1).

- Wastewater discharge for 2017-2018 (Fig. 2).

Having received four web-applications, there are several methods for distributing them:

- Share it via social networks;

- Introduce the map to a thematic web-site;

- Share link with friends and acquaintances.

Web-applications created can be viewed at https://arcg.is/1qCTrm and https://arcg.is/1XrLOW. 


\section{CONCLUSIONS}

Thus, studying the problem of surface water pollution in Lviv region, we can summarize the following.

1. We have collected and systematized geospatial statistical mapping materials on the ecological status of the surface waters of the Lviv region.

2. The necessary software for the development of the interactive map is identified and its possibilities are examined.

3. An algorithm for loading geospatial data into the created web-resource has been developed.

4. We have selected an application template for creating web-maps of the monitoring network of surface waters of Lviv region and wastewater discharge for 2017-2018 in the ArcGIS Online environment.

5. Two interactive web-maps of ecological pollution of surface waters of Lviv region in ArcGIS Online environment have been developed.

1. Департамент екології та природних ресурсів Львівської обласної державної адміністрації / Екологія Львівщини 2016. - Львів: СПОЛОМ, 2017. - 127 с.

2. Департамент екології та природних ресурсів Львівської обласної державної адміністрації / Екологічний паспорт Львівської області за 2017 рік. - Львів: СПОЛОМ, 2018. - 170 с.

3. Департамент екології та природних ресурсів Львівської обласної державної адміністрації / Регіональна доповідь про стан навколишнього природного середовища у Львівській області в 2018 році. Львів: СПОЛОМ, 2019. - 297 с.

4. Согор А.Р., Ярема Н.П., Геба М.С., Серант О.В. Створення екологічних карт Львівщини за даними моніторингу атмосферного повітря // Молодий вчений. - 2018. - №6(58). - С.23-27.

5. Согор А.Р., Ярема Н.П., Бридун А.М., Лех І.П. Створення інтерактивної карти забруднення атмосферного повітря Львівщини // Молодий вчений. - 2019. - № 2(66). - С.303-306.

6. Ярема Н.П., Серант О.В., Кубрак О.Д., Терех Т.М. Веб-картографування сміттєзвалищ Львівської області // Молодий вчений. - 2019. - № 11(75). - С.167-171.

7. Ярема Н.П., Марко Т.Б. Забруднення навколишнього природного середовища твердими побутовими відходами на прикладі Львівської області // Екогеофорум 2017. Актуальні проблеми та інновації: Матеріали міжнародної науково-практичної конференції (Івано-Франківськ, 22-25 березня 2017 р.). Івано-Франківськ, 2017. - С.369-370.

8. Ярема Н.П., Марко Т.Б., Лозинський В.А. Картографування забруднення навколишнього природного середовища Львівщини твердими побутовими відходами // GeoTerrace-2016: Матеріали міжнародної науково-технічної конференції молодих вчених (Львів, 15-17 грудня 2016 р.). - Львів, 2016. C.166-167.

9. Ярема Н.П., Полюхович Ю.М., Кубрак О.Д., Серант О.В. Створення інтерактивної карти сміттєзвалищ Львівської області // Нові технології в геодезії, землевпорядкуванні, лісовпорядкуванні та природокористуванні: Матеріали IX Міжнародної науково-практичної конференції (Ужгород, 4-6 жовтня 2018 р.). - Ужгород, 2018. - С.119-123.

10. Evans A.E., Mateo-Sagasta J., Qadir M., Boelee E., Ippolito A. Agricultural water pollution: key knowledge gaps and research needs // Current opinion in environmental sustainability. - 2019. Vol. 36. - P.20-27. https://doi.org/10.1016/j.cosust.2018.10.003

11. Walker D.B., Baumgartner D.J., Gerba C.P., Fitzsimmons K. Surface water pollution // In: Environmental and pollution science. - Academic Press, 2019. - P.261-292.

https://doi.org/10.1016/b978-0-12-814719-1.00016-1

12. Revitt D.M., Ellis J.B. Urban surface water pollution problems arising from misconnections // Science of the Total Environment. - 2016. - Vol. 551. - P.163-174.

https://doi.org/10.1016/j.scitotenv.2016.01.198

13. Barinova $S$. Ecological mapping in application to aquatic ecosystems bioindication: Problems and methods // Int. J. Envir. Sci. Nat. Res. - 2017. - Vol. 3(2). - P.1-7.

https://doi.org/10.19080/ijesnr.2017.03.555608

14. Ponomarenko S., McLennan D., Pouliot D., Wagner J. High Resolution Mapping of Tundra Ecosystems on Victoria Island, Nunavut-Application of a Standardized Terrestrial Ecosystem Classification // Canadian Journal of Remote Sensing. - 2019. - Vol. 45, Issue 5. - P.551-571.

https://doi.org/10.1080/07038992.2019.1682980

15. Lang $Y$., Song $W$. Quantifying and mapping the responses of selected ecosystem services to projected land use changes // Ecological Indicators. - 2019. - Vol. 102. - P.186-198.

https://doi.org/10.1016/j.ecolind.2019.02.019 


\section{Web-картографування екологічного забруднення поверхневих вод Львівської області \\ Согор A.P., Фис М.M., Бридун А.М., Согор М.A.}

Національний університет «Львівська політехніка», 79013, м. Львів, вул. Карпінського, 6

На екологічний стан поверхневих вод Львівської області впливають тісно пов'язані різноманітні фактори, а саме: забруднення грунтів, атмосфери, зміна ландшафтної структури та техногенне перевантаження території, неефективна робота каналізаційно-очисних споруд, не винесення в натуру картографічних матеріалів прибережних захисних смуг і водоохоронних зон, а також їх недодержання, насамперед в населених пунктах, забруднення і засмічення річок побутовими та іншими відходами, трелювання лісу по потоках у гірській місцевості. Ще однією важливою проблемою, що призводить до забруднення поверхневих вод на території області, є відсутність водоохоронних зон та прибережно-захисних смуг водних об’єктів на території області. Відсутність планово-картографічних матеріалів і невизначеність на місцевості меж водоохоронних зон та прибережних захисних смуг призводять до порушень земельного і водного законодавства при їх використанні. На даний час стан водних об’єктів в Україні та, зокрема, у Львівській області знаходиться на незадовільному рівні. Основними проблемами у цій сфері є прогресуючий характер негативного впливу на екологічний стан довкілля та здоров'я людей. Оскільки на даний час не існує жодного картографічного матеріалу, який може візуалізувати проблему забруднення поверхневих вод Львівщини, головною метою цієї роботи було створення інтерактивної карти забруднення поверхневих вод області. Для досягнення цієї мети нами було зібрано та систематизовано геопросторові статистичні картографічні матеріали щодо екологічного стану поверхневих вод Львівщини. Визначено необхідне програмне забезпечення для розробки інтерактивної карти та вивчено його можливості. Розроблено алгоритм завантаження геопросторових даних у створюваний веб-ресурс. Підібрано шаблон аплікацій для створення веб-карт моніторингової мережі поверхневих вод Львівської області та скиду стічних вод за 2017-2018 роки в середовищі «ArcGIS Online». Таким чином, було розроблено дві інтерактивні карти екологічного забруднення поверхневих вод Львівщини в середовищі «ArcGIS Online».

Ключові слова: геопросторові дані; Держгеокадастр; екологічне картографування; забруднення поверхневих вод; інтерактивна карта; середовище «ArcGIS Online»; середовище «Microsoft Office Excel».

\section{Web-картографирование экологического загрязнения поверхностных вод Львовской области Согор A.P., Фыс M.M., Брыдун А.М., Согор М.А.}

Национальный университет «Львовская политехника», 79013, г. Львов, ул. Карпинского, 6

На экологическое состояние поверхностных вод Львовской области влияют тесно связанные различные факторы, а именно: загрязнение почв, атмосферы, изменение ландшафтной структуры и техногенная перегрузка территории, неэффективная работа канализационно-очистных сооружений, не вынос в натуру картографических материалов прибрежных защитных полос и водоохранных зон, а также их несоблюдение, прежде всего в населенных пунктах, загрязнение и засорение рек бытовыми и другими отходами, трелевки леса по потокам в горной местности. Еще одной важной проблемой, что приводит к загрязнению поверхностных вод на территории области, является отсутствие водоохранных зон и прибрежно-защитных полос водных объектов на территории области. Отсутствие планово-картографических материалов и неопределенность на местности границ водоохранных зон и прибрежных защитных полос приводят к нарушениям земельного и водного законодательства при их использовании. В настоящее время состояние водных объектов в Украине и, в частности, во Львовской области находится на неудовлетворительном уровне. Основными проблемами в этой сфере являются прогрессирующий характер негативного влияния на экологическое состояние окружающей среды и здоровье людей. Поскольку в настоящее время не существует ни одного картографического материала, который может визуализировать проблему загрязнения поверхностных вод Львовщины, главной целью этой работы было создание интерактивной карты загрязнения поверхностных вод области. Для достижения этой цели нами было собраны и систематизированы геопространственные статистические картографические материалы по экологическому состоянию поверхностных вод Львовщины. Определено необходимое программное обеспечение для разработки интерактивной карты и изучены его возможности. Разработан алгоритм загрузки геопространственных данных в создаваемый веб-ресурс. Подобран шаблон приложений для создания веб-карт мониторинговой сети поверхностных вод Львовской области и сброса сточных вод за 2017-2018 годы в среде «ArcGIS Online». Таким образом, были разработаны две интерактивные карты экологического загрязнения поверхностных вод Львовщины в среде «ArcGIS Online».

Ключевые слова: геопространственные данные; Государственная служба геодезии картографии и кадастра; экологическое картографирование; загрязнение поверхностных вод; интерактивная карта; среда «ArcGIS Online»; среда «Microsoft Office Excel».

Надійшла до редакціï / Received
Виправлена авторами / Revised
Прийнята до друку / Accepted 18.10 .2020 23.11.2020 26.11.2020 